\title{
Revision of the late Carboniferous megaflora from the De Lutte-06 well (Twente, the Netherlands), and its stratigraphical implications
}

\author{
I.M. van Waveren ${ }^{1,}{ }^{*}$, O.A. Abbink ${ }^{2}$, T.B. van Hoof $^{2}$ \& J.H.A. van Konijnenburg - van Cittert ${ }^{1}$ \\ 1 Naturalis, P.0. Box 9517, 2300 RA Leiden, the Netherlands. \\ 2 TN0, P.0. Box 80015, 3508 TA Utrecht, the Netherlands. \\ * Corresponding author. Email: waveren@naturalis.nl
}

Manuscript received: December 2007; accepted: 0ctober 2008

\begin{abstract}
Biostratigraphical re-analysis of palaeobotanical data from the De Lutte-06 well clarifies an earlier controversy regarding the stratigraphical interpretation of this well based on palaeobotanical and palynological analysis. Previous biostratigraphical studies suggested an early Westphalian D age for the major part of the De Lutte formation, with only at the topmost part of the well remnants of presumable but unconfirmed Stephanian deposits. New identifications of palaeobotanical samples illustrate the presence of plant macrofossil assemblages in the De Lutte Formation characteristic for the latest Westphalian D to the Stephanian B-C. These new palaeobotanical insights, therefore, confirm a younger age for the De Lutte Formation and are more in line with the earlier palynological observations from the De Lutte-06 well that suggested that the recovered palynofloras resembled typical Stephanian associations.
\end{abstract}

Keywords: Plant biostratigraphy, Westphalian D, Stephanian, Annularia spicata, Odontopteris, palaeobotany, palynology

\section{Introduction}

In 1989, the NAM (Nederlandse Aardolie Maatschappij B.V.) in co-operation with the RGD (Geological Survey of the Netherlands) drilled the De Lutte-06 borehole (eastern part of the Netherlands) into Upper Carboniferous strata (see Fig. 1). In the lithostratigraphic context of the Upper Carboniferous of the Dutch onshore this well represents the type section of the De Lutte Formation that belongs to the Hunze Subgroup of the Limburg Group (Van Adrichem Boogaert \& Kouwe, 1995). The De Lutte Formation is considered to represent the youngest Carboniferous deposits in the Netherlands (e.g., Van Buggenum \& Den Hartog Jager, 2007) and is a lateral equivalent of the Step Graben (Dutch) and Boulton (UK) Formations in the Dutch and British Cleaverbank area (North-Sea) (Van Adrichem Boogaert \& Kouwe, 1995; Besley, 2002). As these deposits in the Cleaverbank area have hydrocarbon reservoir potential there is an increased interest in detailed stratigraphical studies of these formations.

In the De Lutte-06 well the De Lutte Formation consists of a succession of reddish brown to grey-green, silty to very fine-grained sandy mudstones, intercalated with light grey, white and pink fine to medium grained sandstones. The base of this formation is placed at the Itterbeck Horizon that was recognized in the De Lutte-06 well at $2973 \mathrm{~mm}$ depth. The De Lutte Formation is topped off by the Base Permian unconformity, and at the site of the type section, overlain by Middle Permian Rotliegend deposits. Sandstones within the De Lutte Formation are 5 to $15 \mathrm{~m}$ thick; mudstones are between 10 and $100 \mathrm{~m}$ thick (average around $50 \mathrm{~m}$ ). Coal seams are present but thin and rare (Van der Meer \& Pagnier, 1996). Seventy palaeosols were described from the De Lutte Formation (Van der Meer \& Pagnier, 1996; Van der Zwan et al. 1993). They consist of seatearth or gleys, ferralic soils, immature calcic soils and mature calcic soils. These were interpreted as indicative of a slow and gradual transition from tropical-wet to arid and semi-arid conditions. This succession illustrates that during the Late Carboniferous, the region underwent a transition from a tropical wet climate to a more seasonally dry climate (Van der Zwan et al. 1993).

The development of reliable interwell correlations based on seismic, petrophysical, litho- and biostratigraphical 

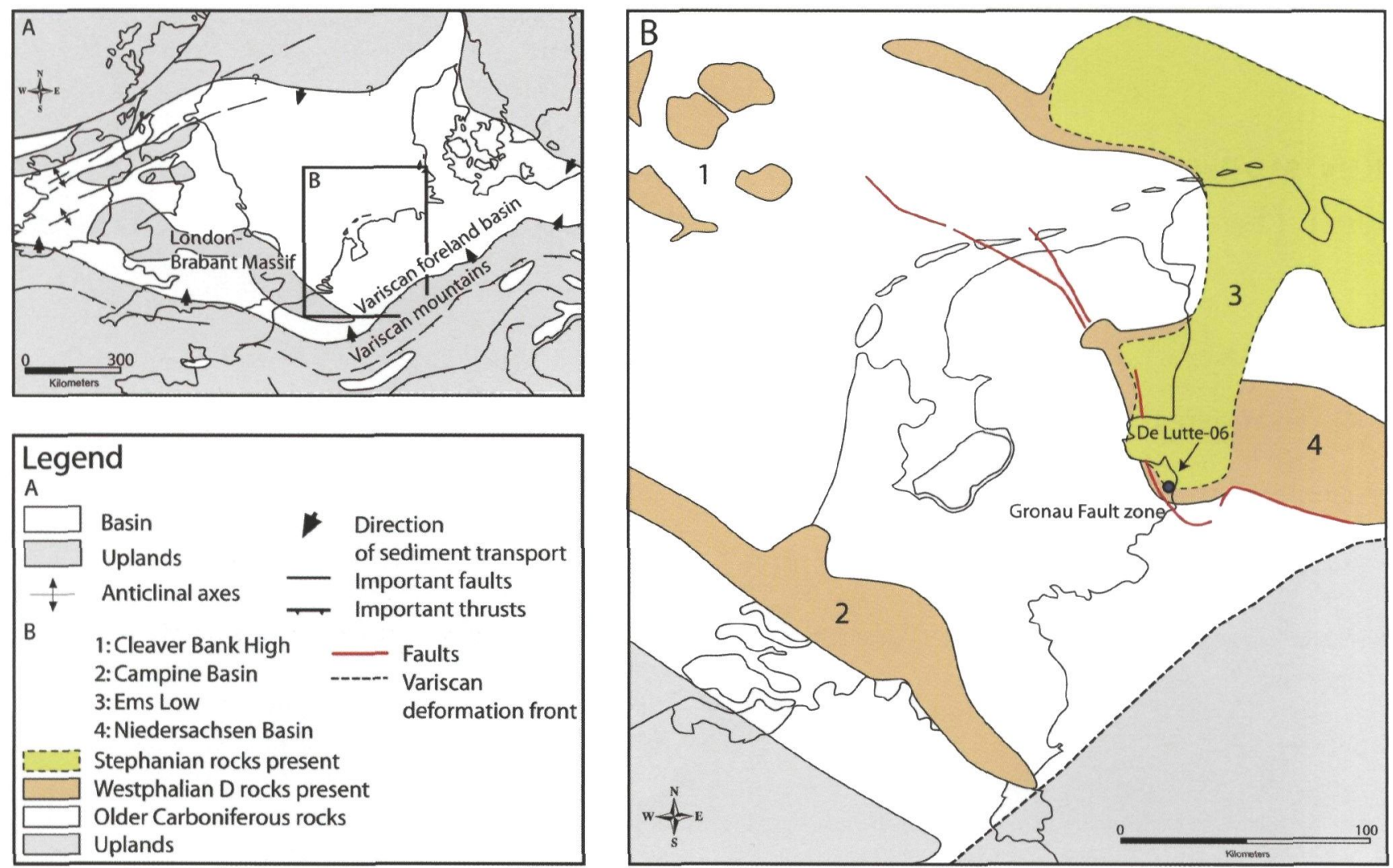

Fig. 1. Location map of the De Lutte 6 well, coloured sections indicate the presence of Westphalian D and Stephanian strata in the subsurface (courtesy of the SPBA project).

interpretations for fluvial and alluvial red bed sequences such as the De Lutte, Step Graben and Boulton formations is difficult. Especially as these red bed sequences in general do not yield very productive biostratigraphical data. Exceptionally, an assemblage of plantmacrofossils together with several intervals containing rather well preserved palynofloras were recovered from the transition of the dark shales to the red beds in the De Lutte-06 well (Van Amerom, 1996a; Van de Laar \& Van der Zwan, 1996). Therefore, the analysis of these macro- and microfossils of the transition to the red bed is most relevant to improve the biostratigraphical framework within the Upper Carboniferous of the Netherlands.

In the original publications on the biostratigraphy of the De Lutte-06 well, a discrepancy was noticed between the palaeobotanical and the palynological age assessment (Van Amerom, 1996a; Van de Laar \& Van der Zwan, 1996). The dating of the De Lutte-06 well was based on palaeobotanical comparisons with the zonal scheme of the Saar-Lorraine Basin defined by Cleal (1984). Despite the possibility of significant timetransgressive first occurrences of floral elements, comparisons were also made with records reported from Spain by Wagner and Alvarez-Vasquez, (1991) and Wales (Wagner \& Spinner, 1974).

The six macrofloral zones on which the De Lutte-06 well were dated are as follows (Van Amerom, 1996a):

- Interval 1 (3206 m - ca 3115 m) - with Neuropteris obliqua, not younger than Westphalian $\mathrm{C}$;
- Interval 2 (ca 3155 m - ca 2815 m) - the Linopteris bunburyi zone (including the base of the De Lutte Formation), Westphalian C;

- Interval 3 (ca 2815 m - ca 2695 m) - the Lobatopteris (Pecopteris) micromiltonii Zone, Westphalian D;

- Interval 4 (2695 m - ca 2575 m) - the Reticulopteris muensteri zone, middle Westphalian $\mathrm{D}$;

- Sub-interval 5 (ca 2600 m - ca 2575 m) - with Walchia (Hermitia) sp., middle Westphalian D;

- Interval 6 (2575 m - $2350 \mathrm{~m}$ ) - with Pecopteris vestita, late Westphalian.

In general, the palynological data suggested a younger age for the De Lutte Formation (Van de Laar \& Van der Zwan 1996). Three successive assemblages were recognized (see also Van der Zwan et al., 1993).

The lower Assemblage I (recorded from the Tubbergen Formation interval 3081.44 - $3193.67 \mathrm{~m}$ (27 samples) is characterized by a dominance of monosaccate pollen. Taeniate and non-taeniate bisaccate pollen are present together with Savistrisporites nux, cf. Lundbladispora gigantea, Cirratriradites saturnii, Vestispora spp., Florinites spp. and Potonieisporites spp.

Assemblage II (from the Itterbeck Horizon, interval 2972.45 - $2973.65 \mathrm{~m}$ (5 samples) is dominated by trilete spores like Calamospora spp. and Lycospora spp.; Laevigatosporites 
spp. and Triquitrites spp. are common. Saccate pollen grains are rare, whereas taeniate bisaccate pollen grains are absent.

The upper Assemblage III (interval 281.85 - $2780.75 \mathrm{~m}$, (14 samples) is dominated by Potonieisporites spp. and/or Endosporites globiformis. Florinites spp., taeniate and nontaeniate bisaccate and monosaccate pollen are common. Cordaitina spp., Illinites unicus and Striatodiplopinites spp., although irregularly found in Assemblage I, represent a very characteristic feature in Assemblage III.

Van de Laar and Van der Zwan (1996) compared the palynological record of the De Lutte well with successions from the UK, Poland, Ukraine and the USA. They stated that the dominance of monolete spores as observed in late Westphalian C to early Stephanian 0T (Thymospora obscura - Thymospora thiessenii) Zone of Clayton et al. (1977) is absent in their data set. As was already mentioned earlier (Van der Zwan et al. 1993), the De Lutte assemblages show more affinity to the NBM (Potonieisporites novicus-bharadwajii-Cheledonites major) Zone of latest Stephanian B to Stephanian 'D' age and the early Autunian VC (Vittatina costabilis) Zone of Clayton et al. (1977). However, based on the very low amount of age diagnostic palynomorphs and in spite of the distinct Stephanian aspects of the pollen record of the De Lutte 6 well, it was decided to adopt the palaeobotanical age interpretations for the palynological record (Van de Laar \& Van der Zwan 1996; Van der Zwan et al., 1993; Van Amerom, 1996a). A late Westphalian C age was assigned to Assemblage I and an early Westphalian D age to Assemblages II and III.

The presence of Stephanian-type or Autunian-type palynofloras during the early Westphalian D was interpreted as related to the early occurrence of local xeric plant communities during the early Westphalian D (Van Amerom, 1996a; Van de Laar \& Van der Zwan, 1996). However recent palynostratigraphical studies of the late Carboniferous of Western Europe do not support the view that precursor Stephanian-type palynofloras may already occur in Westphalian D deposits (McLean et al., 2005; Hartkopf-Fröder, 2005).

A reassessment of the biostratigraphical significance of the De Lutte-06 macroflora is therefore necessary. Comparison with macrofloras from remote areas is avoided as e.g. Neuropteris ovata and $N$. scheuchzeri, relevant in the present study, are considered relicts in North America (Lyons \& Zodrow, 1995). Moreover Sphenophyllum verticillatum, also relevant in the present study, has a range in the far east (China) running from the Yanghukou Formation (situated at the transition from the Namurian and the Westphalian) to the Stephanian (Li et al., 1991) while it has a much more restricted range in central Europe (Remy \& Remy, 1977). Clearly east-west correlations are very complex, and can at best be carried out at a generic level for palaeobiogeographical and nomenclatorial reasons (Hilton and Cleal, 2007). Within Variscan Euramerica, both east-west and north-south correlations are also strongly influenced by biogeographical factors. This can best be inferred from lyginopterid and medullosean assemblages indicating the existence of a Rhine palaeoprovince, distinct from other palaeoprovinces, the Iberian and Silesian in particular (Cleal, 2008a, 2008b). Indeed Variscan Euramerica is the object of divergent palaeogeographical reconstructions (Scotese, 2005, Shi, 2006, Stampfli \& Borel, 2004). Moreover the rapid shrinking of the coal forming wetlands at the Permo-Carboniferous transition indicates that Variscan Euramerica was a palaeoecologically sensitive area. The macro- and microfossil record has to be a function of the plate movement, the local palaeogeography on either side of the Variscan mountains, or of the changing width of the palaeoecological zones. For the purpose of age assessment it is therefore crucial to correlate within the palaeoprovince of the De Lutte-06 well, e.g. the Rhine palaeoprovince (Cleal, 2008b , fig 1). Several important wells (including the Itterbeck-Halle 5, Norddeutschland 8 and Freswegen 5) located very close to the Dutch-German border (Josten, 1995) belong in the Rhine palaeoprovince.

Considerable knowledge on the middle and late Carboniferous macrofloras (Namurian to Westphalian D) was already made available in a standard work (Josten, 1991) based on various earlier studies (Josten 1966; 1970; Josten \& Teichmüller, 1971; Josten \& Laveine 1984) but more specifically a study of the late Carboniferous-Permian transition (Westphalian D, Stephanian and Rotliegend) was also published lately (Josten \& Van Amerom, 1999). A comprehensive compilation of all of these late Carboniferous macrofossil records from NW Germany has now become available (Josten, 2005).

Comparison with this extensive data set specific to the Rhine palaeoprovince, in association with a critical reappraisal of the available macroflora remains from the De Lutte-06 well will provide the appropriate basis for the age-assessment of the De Lutte-06 macroflora. Therefore, in order to resolve the apparent controversy between palaeobotanical and palynological results, this paper is focusing on an update and stratigraphical reanalysis of the palaeobotanical data from the De Lutte-06 well.

\section{Material and Methods}

The present study uses the biostratigraphic occurrences of plant macrofossils as described from wells drilled in the vicinity of the De Lutte in northwestern Germany (Josten 2005). Together with additional sampling of the wells and an update of the taxonomy, these stratigraphical ranges of the taxa from a nearby basin will provide a more up to date view on the problems related to the biostratigraphical framework of the De Lutte-06 well. Since this study deals with data from Western Europe, age interpretations are expressed in accordance to the regional chronostratigraphical scheme as recently modified by the IUGS Subcommission on Carboniferous Stratigraphy (Heckel \& Clayton, 2006). Approximate equivalency of regional terrestrial substages to global stage subdivision is indicated in Figure 2. 


\begin{tabular}{|c|c|c|c|c|}
\hline \multicolumn{2}{|c|}{ Global } & \multirow{2}{*}{$\begin{array}{c}\text { Age } \\
\text { Menning (2005) }\end{array}$} & \multirow{2}{*}{$\begin{array}{c}\text { West and Central Europe } \\
\text { Regional substage }\end{array}$} & \multirow{2}{*}{$\begin{array}{l}\text { Netherlands } \\
\text { (present study) }\end{array}$} \\
\hline Series & Stage & & & \\
\hline Permian & Asselian & $207 ?$ & & \\
\hline \multirow{7}{*}{ 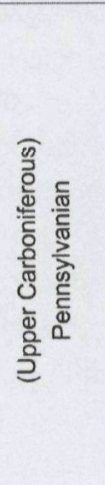 } & \multirow{3}{*}{ Gzhelian } & & $\begin{array}{l}\text { Base Permian } \\
\text { (lower) Autunian }\end{array}$ & Unconformity \\
\hline & & $\begin{array}{c}300.0 \\
\pm 2,4\end{array}$ & Stephanian C & Stephanian C \\
\hline & & -302 & Stephanian B & Stephanian B \\
\hline & \multirow[t]{2}{*}{ Kazimovian } & & Stephanian A, Barruelian & Stephanian A \\
\hline & & 305 & Cantabrian & (Cantabrian) \\
\hline & \multirow{2}{*}{ Moscovian } & & Westphalian D, Asturian & Westphalian D \\
\hline & & & Westphalian C, Bolsovian & Westphalian C \\
\hline
\end{tabular}

Fig. 2. Global and regional chronostratigraphical subdivision charts of the Pennsylvanian (Upper Carboniferous) Permian transition (after Menning et al., 2005).

The specimens used in this report are housed in the National Museum of Natural History in Leiden, Naturalis. All available specimens of Van Amerom (1996a) were re-examined. The De Lutte-06 core (TN0) was re-sampled for additional plant macrofossils. During our new sampling of the De Lutte-06 core no new species were observed. Only one new specimen, Annularia sphenophylloides, was added to the flora list.

All specimens were assigned an exact core depth; these are used to indicate which specimens are exactly meant in the description, because previously used sample numbers appeared to be confusing. For sake of security, the depth in the core is used here as the sample number.

The uncertainty of age assignment based on the palaeontological content is expressed according to the conventions established for the International Stratigraphic Guide (Murphy \& Salvador, 1999).

\section{Results}

\section{Identifications of the De Lutte-06 macrofloral elements}

Hepaticites tortuosus Van Amerom

\section{Description}

Thin ribbon-like fragments of about $0.5 \mathrm{~cm}$ wide and $3 \mathrm{~cm}$ long with a mid vein are observed (see also van Amerom, 1996b).

\section{Chronostratigraphical range}

Not relevant.

\section{Occurrence depth}

$2781.29 \mathrm{~m}$

\section{Calamites sp.}

\section{Description}

Fragments where the intermodal distance is larger than the diameter of the stem. Furrows thin, 10 - 14 per centimetre.

\section{Chronostratigraphical range}

Devonian to end Permian.

\section{Occurence depth}

$3029,65-2308.69 \mathrm{~m}$.

\section{Annularia sphenophylloides (Zenker) Gutbier (Fig. 3)}

\section{Description}

Internode length approximately $10 \mathrm{~mm}$. Thickness of the axis unknown. Whorls have 14 to 16 leaves, 4 to $5 \mathrm{~mm}$ long and $1.5 \mathrm{~mm}$ wide. Leaves symmetrically spatulate to ellipsoidal, no midvein visible, occasionally mucronate.

\section{Remarks}

The leaves observed here sometimes are ellipsoidal and consequently resemble the variability observed by Lesquereux (1880) in North American deposits.

\section{Chronostratigraphical range in North West Germany \\ Westphalian A to Autunian (Josten, 2005).}

\section{Occurrence depth}

2518.62 - $2569.70 \mathrm{~m}$.

\section{Annularia spicata Gutbier (Fig. 4)}

\section{Description}

Very small whorls with 6 to 8 leaves. Leaves with rather obtuse apices and parallel sides, length 2 to $3 \mathrm{~mm}$ and width $1 \mathrm{~mm}$ or less, widest point if detectible, in the distal half of the leaf, no midvein.

\section{Remarks}

Annularia spicata and $A$. galioides have often been confused because they are of the same size and have a similar number of leaves per whorl (Jongmans, 1911; Crookall, 1969). The leaf shape of in our specimen differs from that of $A$. galioides in 


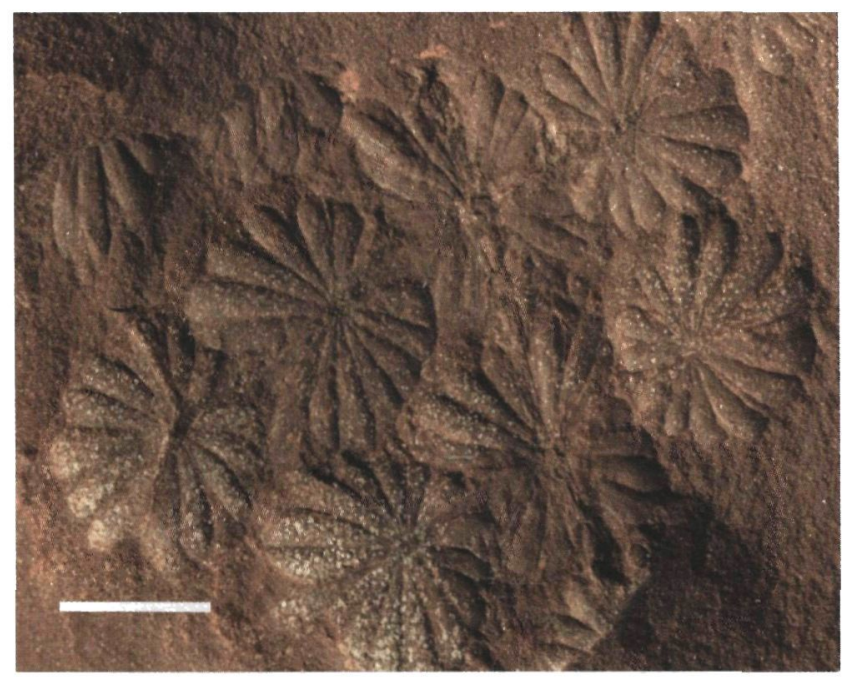

Fig. 3. Annularia sphenophylloides (scale bar $=1 \mathrm{~cm}$ ).

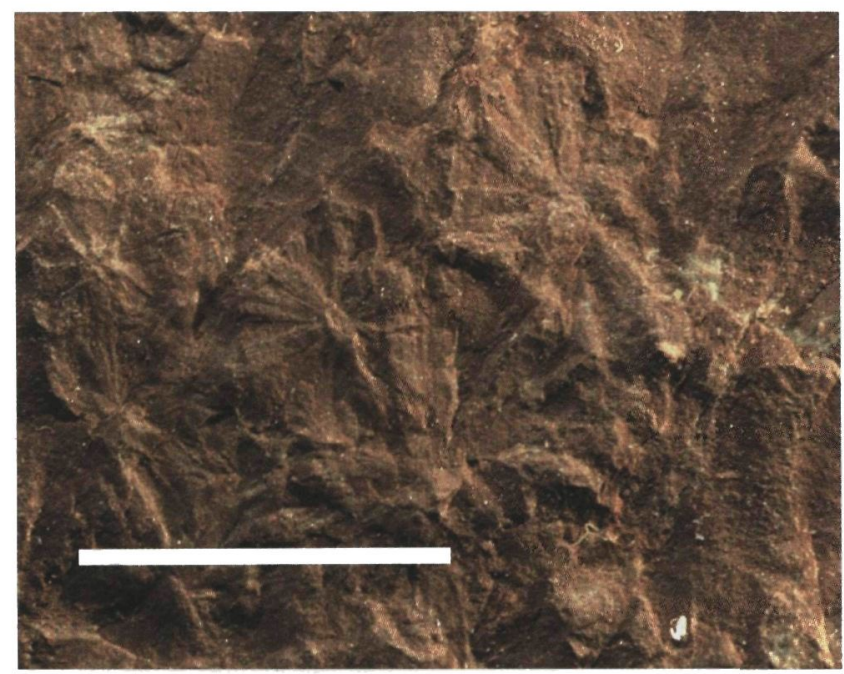

Fig. 4. Annularia spicata $($ scale bar $=1 \mathrm{~cm})$.

having the widest point in the apical part. This is a diagnostic feature of $A$. spicata. For this reason we refer the material identified earlier as $A$. galioides to $A$. spicata.

\section{Chronostratigraphical range in North West Germany}

Stephanian B to C (Josten, 2005).

\section{Occurrence depth}

$2547.0 \mathrm{~m}$.

Sphenophyllum verticillatum (Schlotheim) Brongniart (Fig. 5)

\section{Description}

The available material consists of a single whorl of 6 approximately equal-sized symmetrical leaves 5 to $7 \mathrm{~mm}$ long and $3 \mathrm{~mm}$ wide. Veins bifurcate, tips rounded, rare teeth on margin.

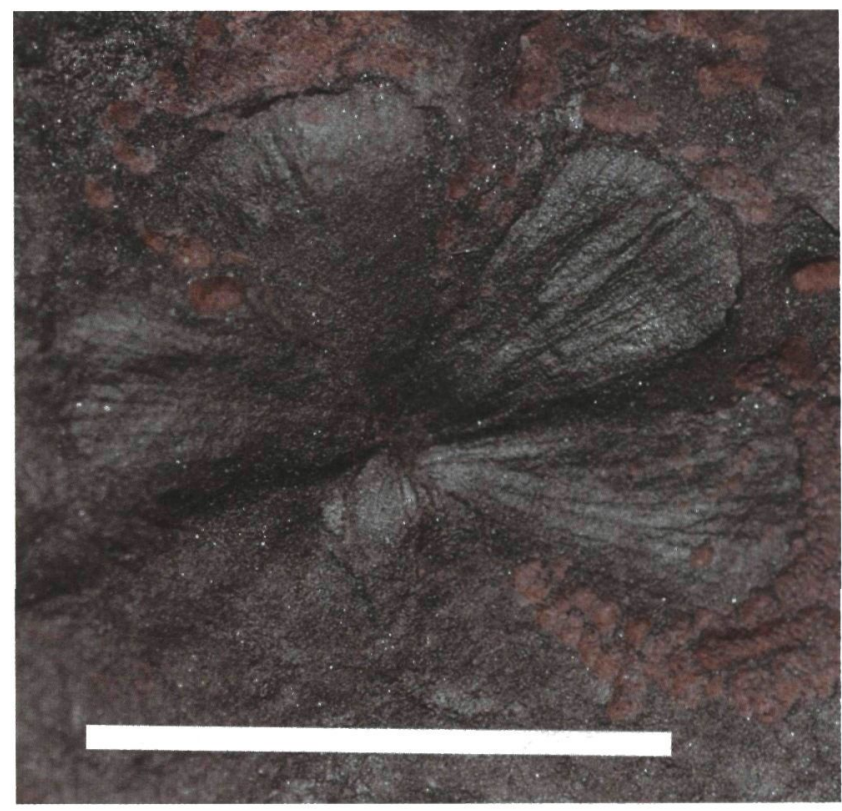

Fig. 5. Sphenophyllum verticillatum (scale bar $=1 \mathrm{~cm})$.

\section{Remark}

According to Batenburg (1977) Sphenophyllum verticillatum (Schlotheim) was invalidly published, he suggested the name Sphenophyllum marsiliaefolium. Although he was correct, his proposal did not find broad acceptance.

\section{Chronostratigraphical range in North West Germany}

Stephanian A to B (Josten, 2005).

\section{Occurrence depth}

$2587.53 \mathrm{~m}$.

Sphenophyllum emarginatum (Brongniart) Brongniart (see Van Amerom, 1996 a, plate 1, fig. 2)

\section{Description}

A sphenophyll with leaves with short apical teeth. The preservation is not very good.

\section{Remarks}

Van Amerom (1996a) identified this as S. cuneifolium, without a description. The specimen that was illustrated in Van Amerom (1996a) is identified here as S. emarginatum because where the teeth are visible, they are too short, too rounded and too frequent to identify this taxon as $S$. cuneifolium. Spenophyllum cuneifolium has fewer, longer and more pointed narrower teeth.

\section{Chronostratigraphical range in North West Germany} Upper Westphalian B to Stephanian C (Josten, 2005).

\section{Occurrence depth}

$2518 \mathrm{~m}$. 


\section{Description}

Pinnae $7-10 \mathrm{~mm}$ long and 2.5 to $3 \mathrm{~mm}$ wide. Minute pinnules $1-1.5 \mathrm{~mm}$ long and 0.5 to $1 \mathrm{~mm}$ wide. Pinnules clearly individualized with a sunken midvein. Secondary veins bifurcate at least once and at a small angle. Veins arise from the midvein and bend towards the apical margin.

\section{Chronostratigraphical range in North West Germany}

Upper Westphalian D (Josten, 2005).

\section{Occurrence depth}

$2781.15-2887.9 \mathrm{~m}$.

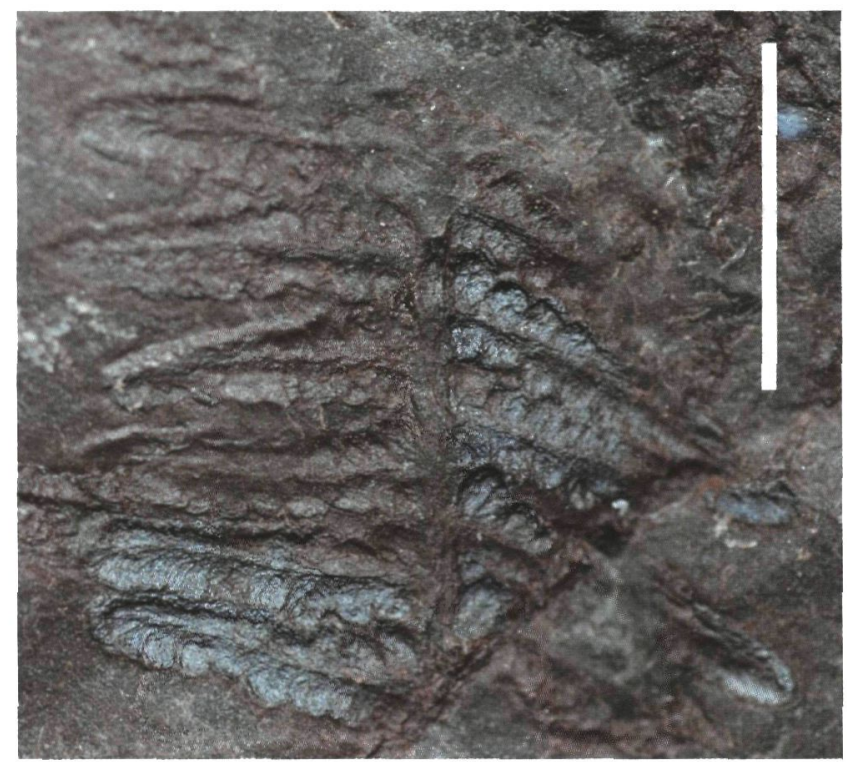

Fig. 6. Lobatopteris micromiltonii (scale bar $=1 \mathrm{~cm})$.

\section{Lobatopteris lamuriana (Heer) Wagner (Figs $7 \mathrm{a}$ and $7 \mathrm{~b}$ )}

\section{Description}

Rounded obtuse lobate pinnules, length 4.5 to $5.5 \mathrm{~mm}$, width of $3 \mathrm{~mm}$, arising from the rachis at approximately $30^{\circ}$. Lateral veins branching at an angle of approximately $45^{\circ}$ and slightly decurrent at the midvein. Veins straight, bifurcating first near midvein and again more than half way to the laminar margin.

\section{Remark}

The terminal pinnule is more acute than in P. vestita.

Chronostratigraphical range in North West Germany Middle Westphalian D to Stephanian C (Josten, 2005).

\section{Occurrence depth}

2699 and $2781 \mathrm{~m}$.

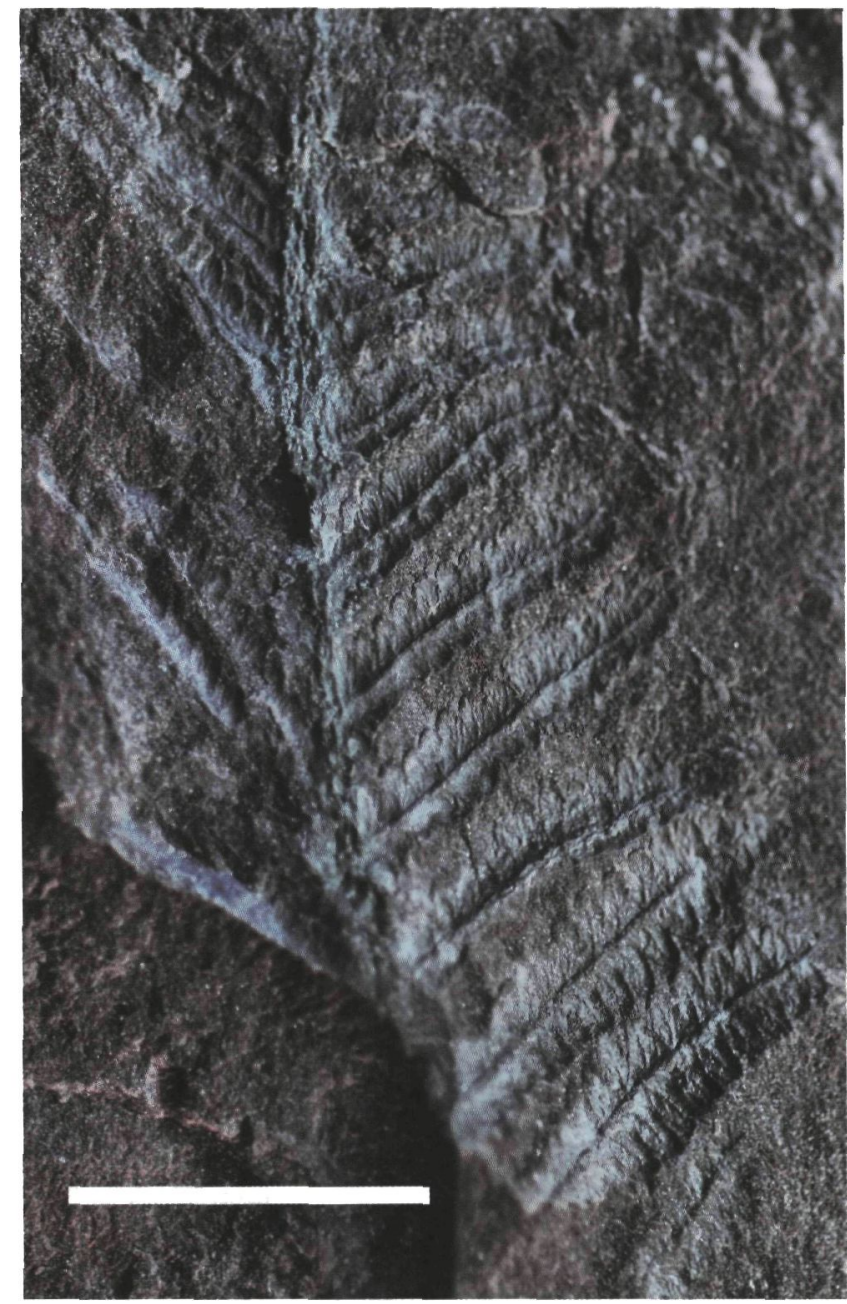

Fig. 7a. Lobatopteris lamuriana (scale bar $=1 \mathrm{~cm}$ ).

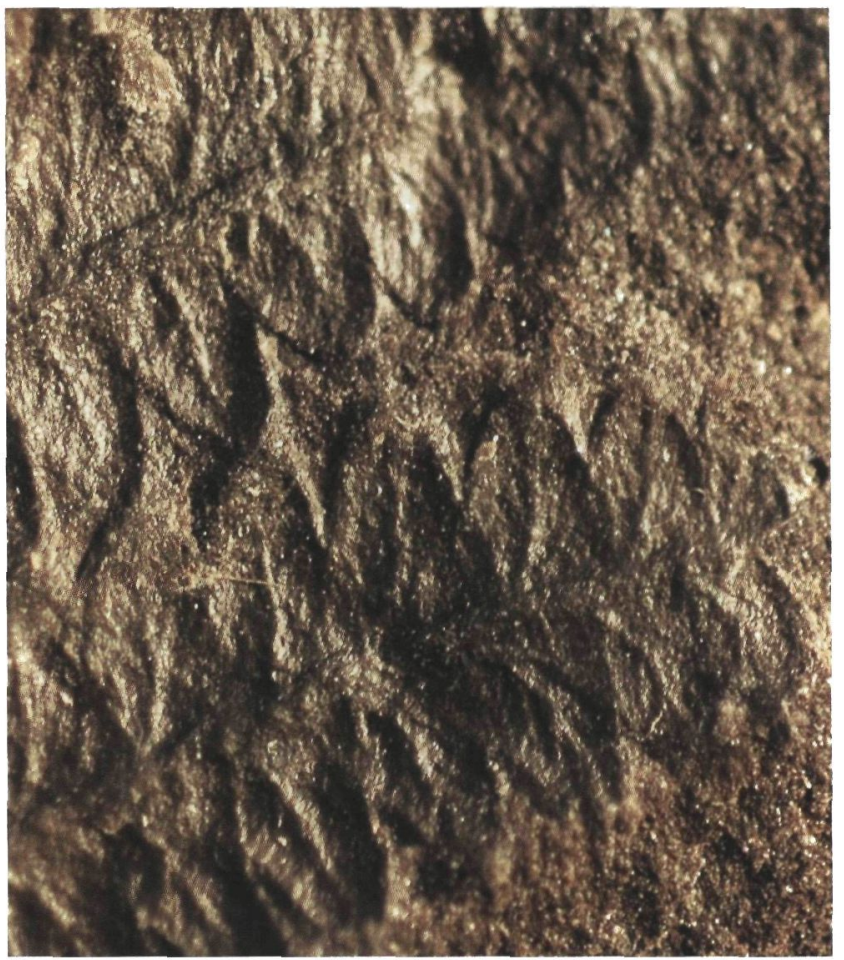

Fig. 7b. Detail of pinnule venation of Lobatopteris lamuriana. 


\section{Description}

A single apical fragment with radiating veins was recovered. The fragment is about $2.5 \mathrm{~cm}$ long. The pinnules are oval. The apex is rounded. The pinnules are $10 \mathrm{~mm}$ long and $5 \mathrm{~mm}$ wide with loosely spaced veins. Veins are faint but when visible, the pinnules is fed by several veins leaving the rachis (see Fig. 9). These features are found in odontopterids.

\section{Remarks}

It is hard to differentiate between different odontopterid based small fragments, but the pinnule shape is more similar to 0 . schlotheimii than to 0 . subcrenulata which has more rounded pinnules, higher vein density and overlapping pinnules. The specimens observed in Spain (Wagner et al., 1969), have smaller more slender pinnules than Odontopteris schlotheimii, and are believed to represent a different species which was called Odontopteris cantabrica Wagner. The occurrence in the lower Cantabrian, was considered as a diagnostic feature. The validity of the species is not questioned, but only its justification as further study of the cuticule of Odontopteris schlotheimii could still prove to support the establishment of Odontopteris cantabrica Wagner (Cleal et al., 2007).

Odontopteris cantabrica is mentioned in a listing of the species found in the Heusweiler formation (Stephanian B) of the Saar-Nahe basin (Kerp et al., 2007). Considering the diagnosis (Wagner et al., 1969), this would not be possible; on the other hand, if Odontopteris schlotheimii and Odontopteris cantabrica are the same species than this extends the range of Odontopteris schlotheimii into the Cantabrian or the range of Odontopteris cantabrica up to the Stephanian B.

\section{Chronostratigraphical range in North West Germany}

Stephanian (Josten, 2005; Josten \& Van Amerom, 1999).

N.B. Odontopteris schlotheimii was validly described by Brongniart (1828) and is typical of East Germany where it was found by Schlotheim in Rotliegend deposits from Thuringia (Brongniart, 1828). Thuringian upper Palaeozoic deposits belong to the central Bohemian palaeoprovince (Cleal, 2008b), consequently this range is not considered relevant in the present study. The French Stephanian basins from central France also hold Odontopteris schlotheimii (Doubinger et al., 1995; Zeiller, 1880). These small pull-apart limnic basins might represent atypical local microclimates and utmost caution is requested for detailed age evaluation of these complex basins. Based on the palaeoprovincial affinities of the euramerican coal basins (Cleal, 2008b), the French central basins are here expected to have Iberian/ Silesian affinities. These basins cannot be used for calibrating the macrofloral associations from the Rhine palaeoprovince.

\section{Occurrence depth}

$2781.45 \mathrm{~m}$.

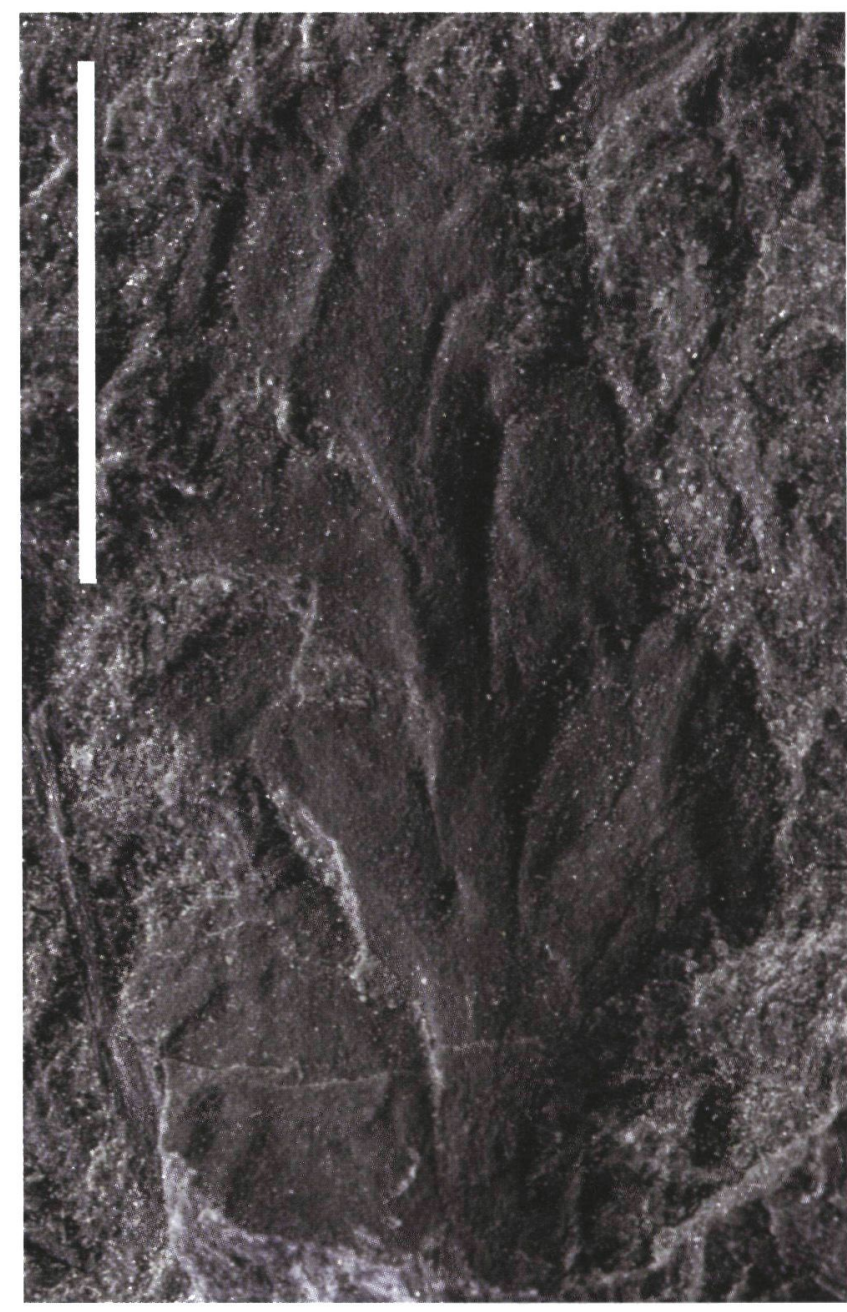

Fig. 8. Odontopteris schlotheimii (scale bar $=1 \mathrm{~cm}$ ).

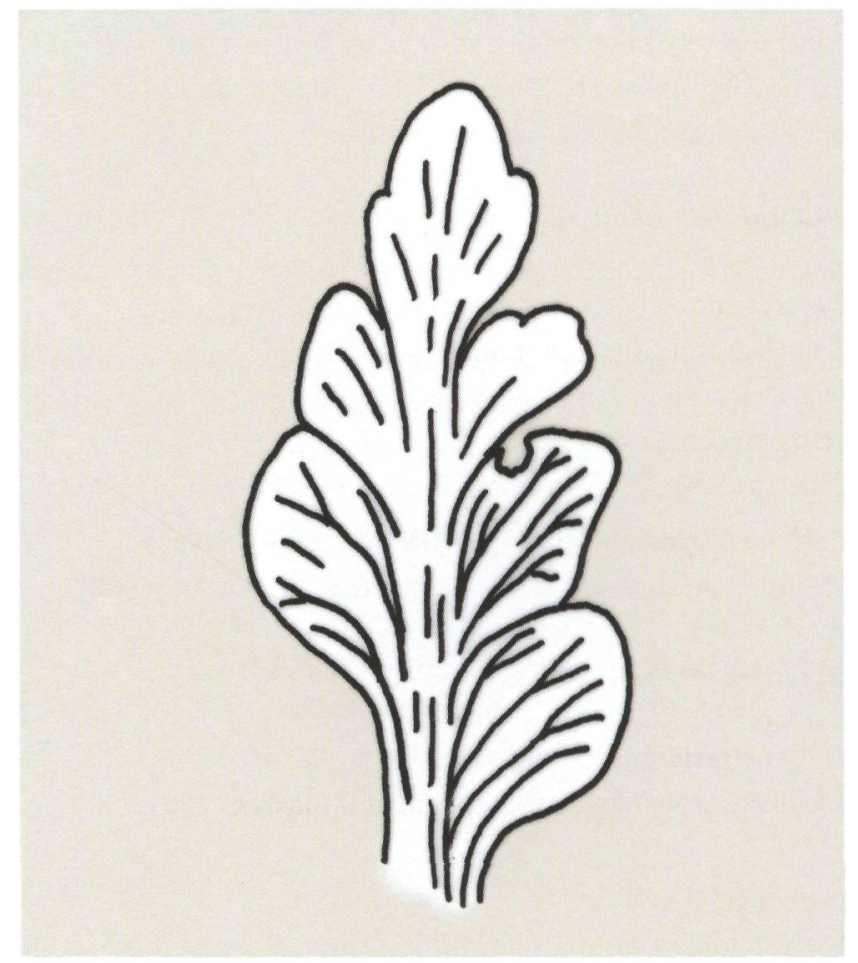

Fig. 9. Venation of Odontopteris schlotheimii. 


\section{Description}

Pinnule with clear midvein reaching until one third of the pinnule, dense venation. This is diagnostic for Neuropteris ovata (Josten, 1991).

\section{Chronostratigraphical range North West Germany}

Westphalian D (Josten, 2005).

\section{Occurrence depth}

$2781.54 \mathrm{~m}$.

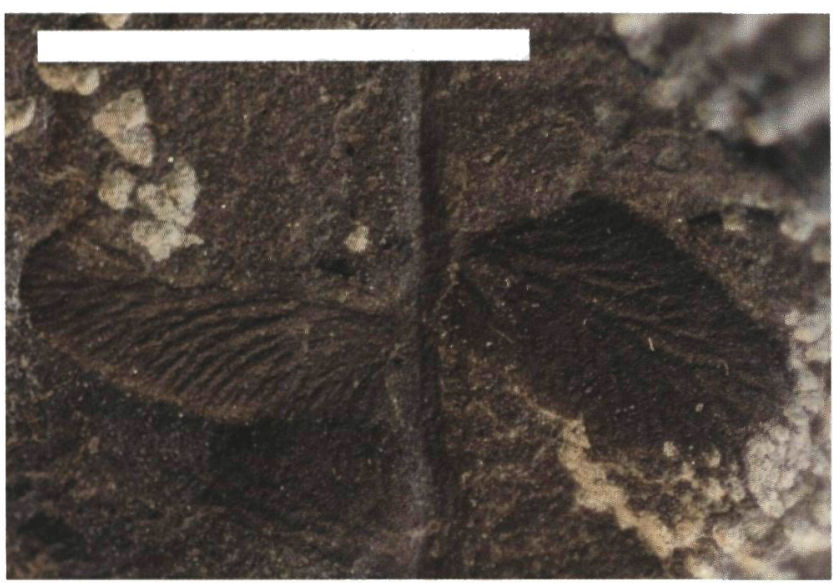

Fig. 10. Neuropteris ovata $($ scale bar $=1 \mathrm{~cm})$.

Neuropteris scheuchzeri Hoffmann (Figs 11 and 12)

\section{Description}

Several elongated pinnules with strongly decurrent, very fine, bifurcating venation. Clear midvein. Single fragment clearly shows apical tapering part of pinnule.

\section{Remark}

Neuropteris scheuchzeri can easily be recognized by the rather large hairs on the upper pinnule surface. These are however not observed on the present specimen. In North America a similar form is found in the Appalachian coalfields, also without these hairs (pers. comms H. Kerp, 2008).

\section{Chronostratigraphical range in North West Germany}

Westphalian B, C and lower Westphalian D (Josten, 2005).

\section{Occurrence depth}

$3165 \mathrm{~m}$.

\section{Neuropteris obliqua (Brongniart) Zeiller (Fig. 13)}

\section{Description}

Lax pinnule venation, midvein running till three quarters of the length of the pinnule.

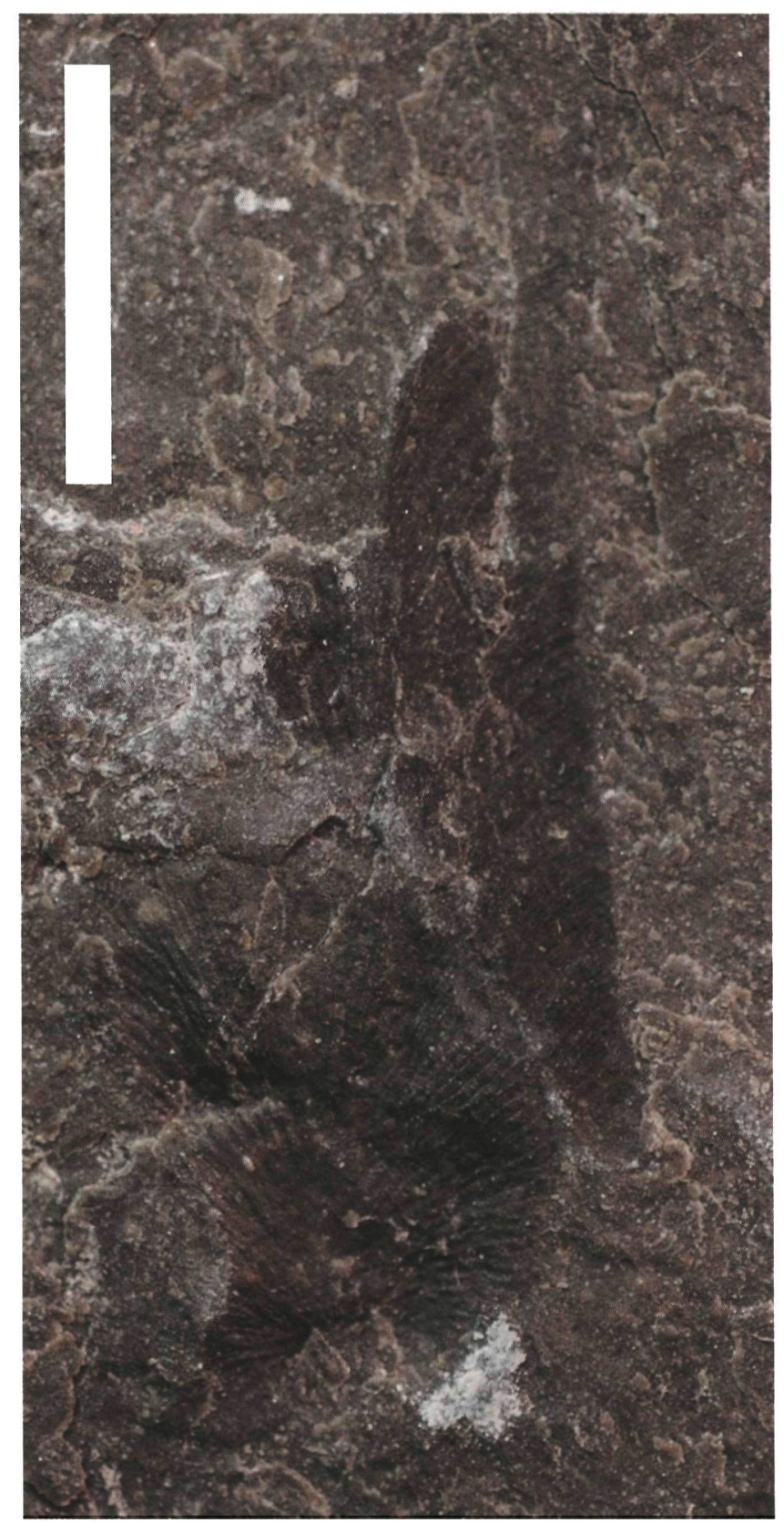

Fig. 11. Badly preserved Neuropteris scheuchzeri with elongated apical part of pinnule (scale bar $=1 \mathrm{~cm})$.

\section{Chronostratigraphical range in North West Germany}

Namurian to Westphalian D (Josten, 2005).

\section{Occurrence depth}

$3128.9 \mathrm{~m}$.

\section{Cordaites principalis (Germar) Geinitz}

\section{Description}

Slender tips of leaves are observed in the cuttings. Vein alternations between thicker and thinner veins irregular, 3 - 5 thinner veins observed between the thicker ones. 


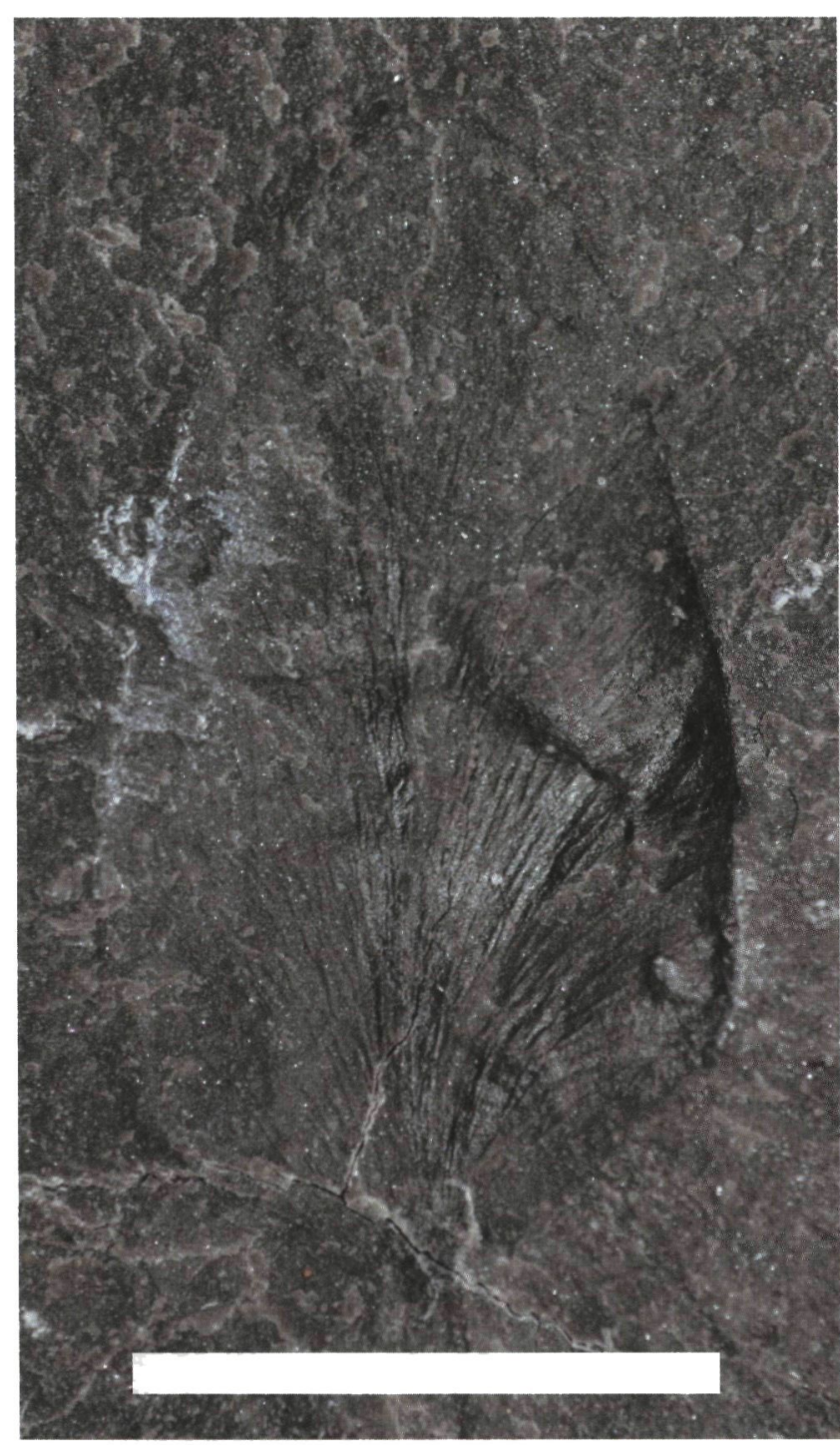

Fig. 12. Atypical well preserved Neuropteris scheuchzeri pinnule (scale bar $=1 \mathrm{~cm})$.

Chronostratigraphical range in North West Germany Namurian to Stephanian (Josten, 2005).

\section{Occurrence depth}

2268.19 and $3042.68 \mathrm{~m}$.

\section{Hermitia (Walchia) sp. (Fig. 14)}

\section{Description}

Clear but small falcate needles $10 \mathrm{~mm}$ long on a small twig were identified in the dark grey shales deeper in the core, also a whole branch of $10 \mathrm{~cm}$ length with alternating twigs in one plane on each side of the main rachis was observed in the red shales higher up in the core.

\section{Remark}

Hermitia is a morphogenus used for walchian remains that do not posses reproductive structures nor a cuticle.

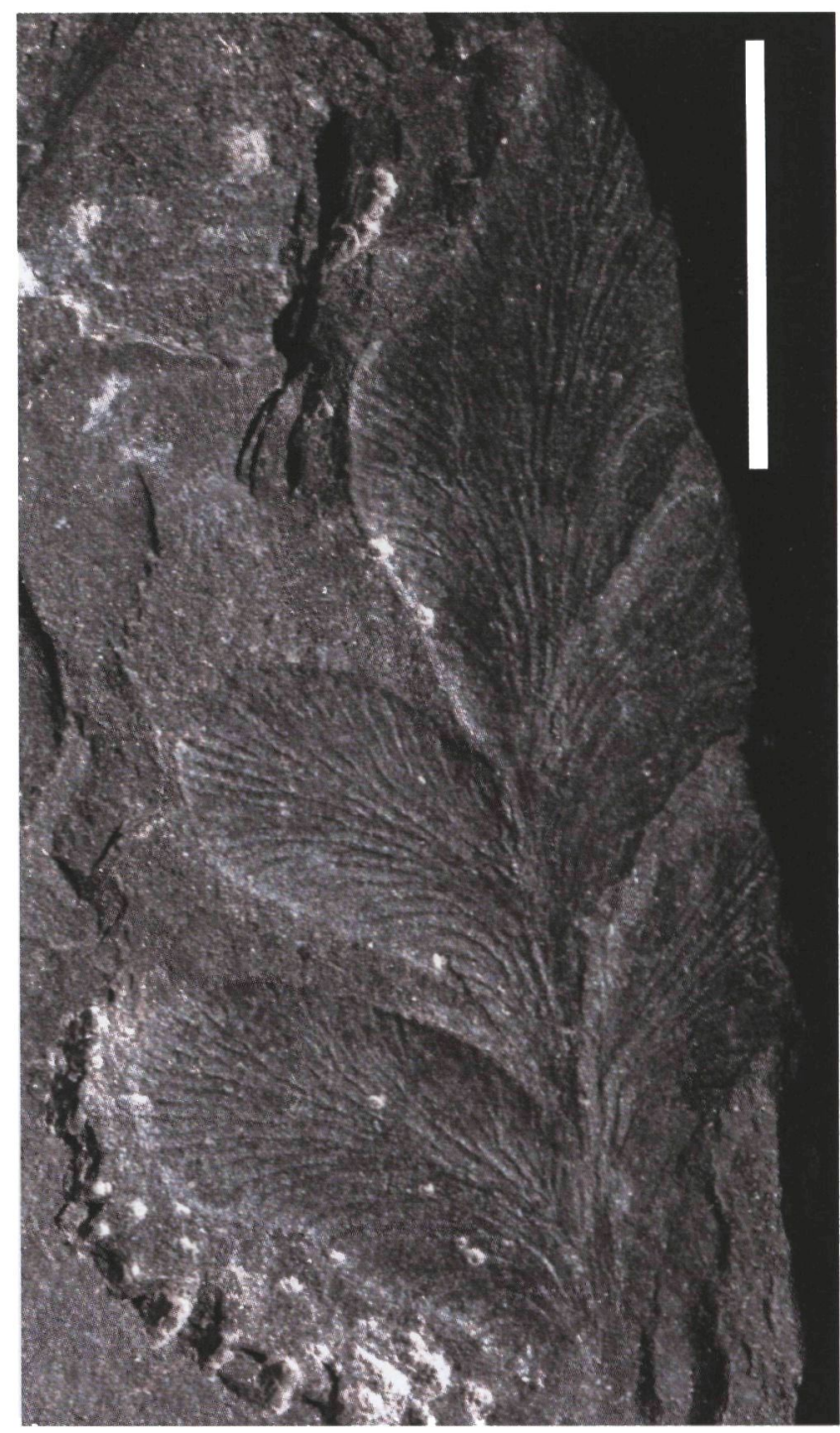

Fig. 13. Neuropteris obliqua (scale bar $=1 \mathrm{~cm})$.

Chronostratigraphical range in North West Germany

Upper Stephanian to Autunian (Josten, 2005).

\section{Occurrence depth}

2589.5 and $2781.57 \mathrm{~m}$.

\section{Age interpretation (see Fig. 15)}

\section{Interval 2518 - $2547 m$ - Stephanian B - C}

The top boundary of this interval is defined by what is considered the last occurrence date (LOD) of Sphenophyllum emarginatum at $2518.00 \mathrm{~m}$. The lower boundary is defined by the occurrence of Annularia spicata at $2547.45 \mathrm{~m}$ depth (single occurrence in well). In NW Germany $S$. emarginatum has its LOD in the Stephanian $C$ while $A$. spicata was found in the Stephanian B and C (Josten, 2005). Therefore this interval is considered to be Stephanian B - C in age. 


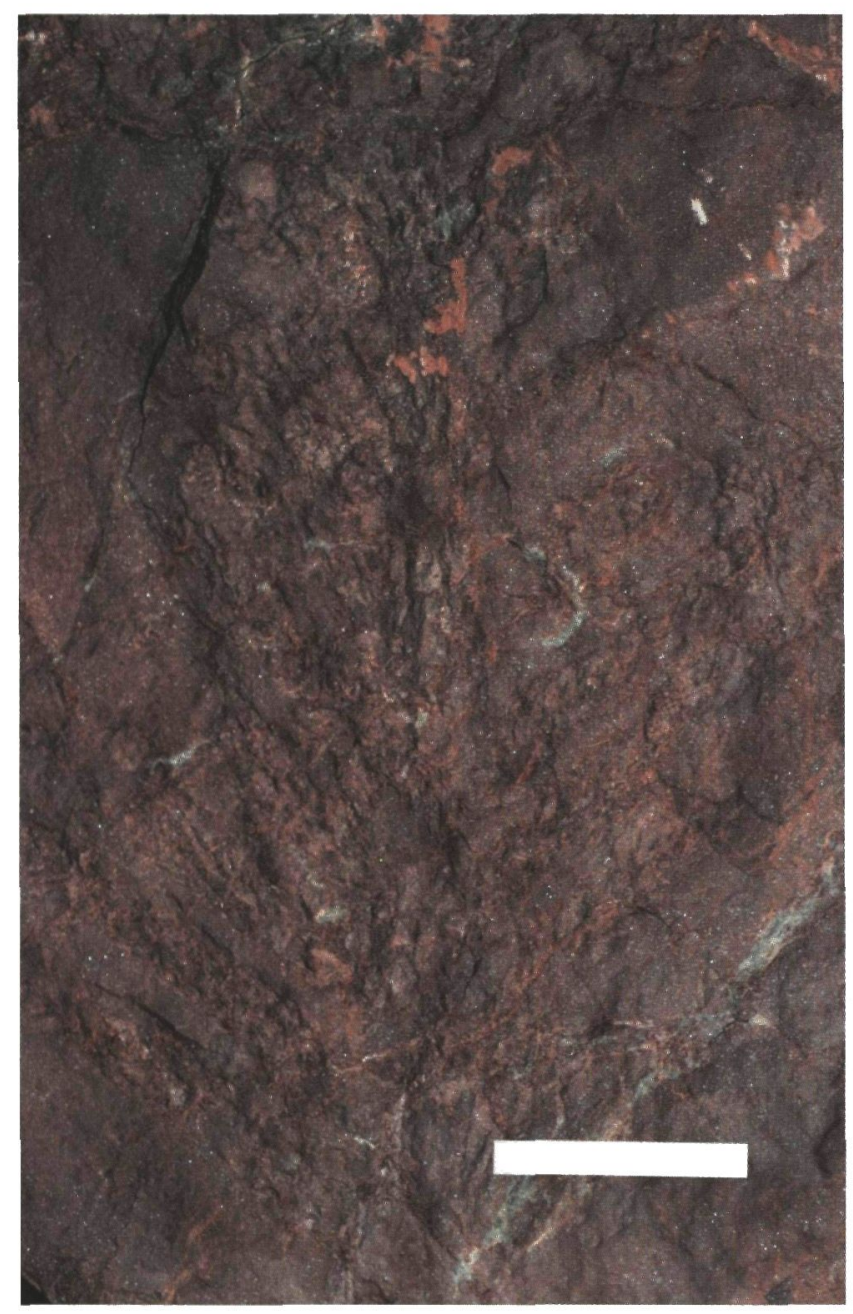

Fig. 14. Hermitia (Walchia) sp. branch with typical symmetrical vegetative shoots sprouting on either side of a main axis (scale bar $=1 \mathrm{~cm})$.

Interval $2587-2781 m-$ Stephanian $A-B$

The top of this interval is defined by the LOD of Sphenophyllum verticillatum at $2587.53 \mathrm{~m}$. The base of this interval is defined by the FOD of Lobatopteris lamuriana at $2781 \mathrm{~m}$ depth. In NW Germany Sphenophyllum verticillatum has a range of Stephanian A - B (Josten, 2005). Pecopteris lamuriana has a range in NW Germany of middle Westphalian D to Stephanian C (Josten, 2005). Within this interval at $2589.5 \mathrm{~m}$ Hermitia (Walchia) sp. was observed. In NW Germany this taxon first appears in the macrofloral record of the late Stephanian (Josten, 2005). It should be noted, however, that earlier appearance dates for conifers have been reported in Desmoinesian (approximately Westphalian D) of North America (Lyons \& Darrah, 1989; Rothwell et al., 1997; Hernandez-Castillo et al., 2001) but also in Great Britain (Scott, 1974), and in NW Germany, in Ibbenbüren, in Westpahalian D deposits (Raabe and Remy, 1964). Based on the age of the underlying interval, this interval is considered to be of Stephanian A -B age.
Interval 2781.24 - $2781.45 m$ - earliest Stephanian (Cantabrian)

The top of this interval is defined by the LOD of Lobatopteris micromiltonii at $2781.15 \mathrm{~m}$ depth. The base of the interval is defined at the FOD of Odontopteris schlotheimii at $2781.45 \mathrm{~m}$ depth (single occurrence in well). This interval is characterized by the co-occurrence of Lobatopteris micromiltonii (at 2781.35 $\mathrm{m}$ and $2781.24 \mathrm{~m}$ ) and Odontopteris schlotheimii (2781.45 m). In NW Germany, Lobatopteris micromiltonii is restricted to the late Westphalian D (Josten, 2005). Odontopteris schlotheimii has a narrow range in NW Germany and is typical of Stephanian deposits (Josten, 2005). The co-occurrence of these taxa in this interval is typical and can be interpreted to represent an earliest Stephanian age, where a relict Westphalian D taxon (Lobatopteris micromiltonii) persists into the earliest Stephanian (Cantabrian). Therefore this interval is considered to be of earliest Stephanian age.

Remark: in the absence of a cuticle from Odontopteris schlotheimii it cannot be decided if this odontopterid is 0 . cantabrica typical of the early Cantabrian (Cleal et al., 2007).

\section{Interval $2781.54 m-2887.90 m$ - Westphalian D}

The top of this interval is placed at the LOD of Neuropteris ovata at $2781.54 \mathrm{~m}$ depth (single occurrence in well). The base of this interval is placed at the FOD of Lobatopteris micromiltonii at $2887.9 \mathrm{~m}$ depth. Neuropteris ovata has a stratigraphical range of Westphalian D and Lobatopteris micromiltonii is restricted to the Westphalian D in NW Germany. Therefore this interval is considered to be of Westphalian D age.

Interval 3128.9 - 3165 m - early Westphalian D or older

The top of this interval is placed at the LOD of Neuropteris obliqua at $3128.9 \mathrm{~m}$ depth (single occurrence in well). The base of this interval is placed at the FOD of Neuropteris scheuchzeri at $3164.5 \mathrm{~m}$. depth (single occurrence in well). In NW Germany Neuropteris obliqua has a range of Namurian to Westphalian D while Neuropteris scheuchzeri has its LOD in the early Westphalian D. This interval is therefore considered to be of early Westphalian D or older age.

\section{Discussion}

The present biostratigraphical interpretation based on plant macrofossils suggests a Westphalian D to Stephanian age for the De Lutte Formation. In the De Lutte-06 well the revised biostratigraphical interpretation lowers the Westphalian/ Stephanian boundary by about 430 meters compared to earlier interpretations (Van Amerom 1996a, Van der Meer \& Pagnier, 1996). 


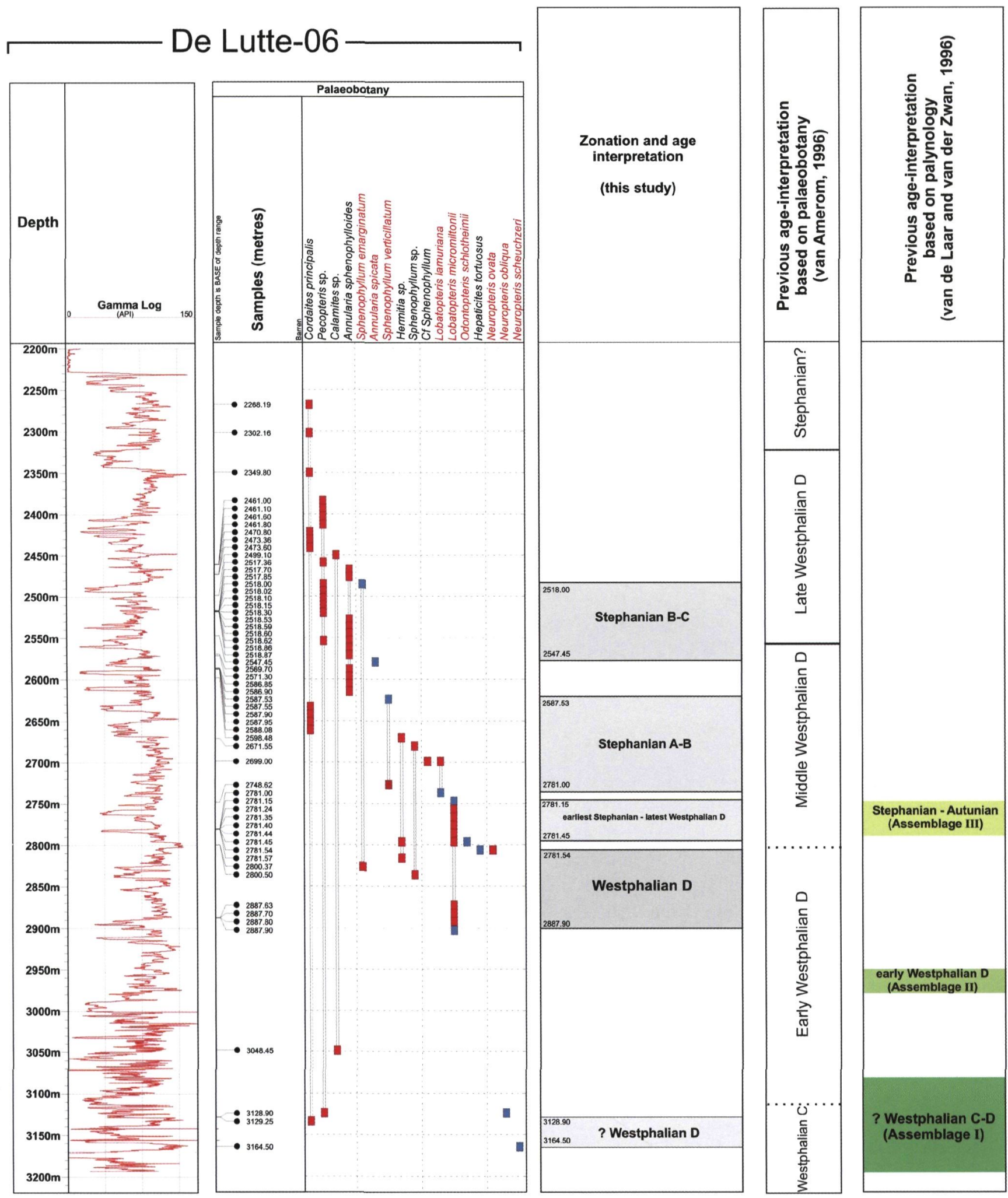

Fig. 15. Revised chronostratigraphical interpretation of the De Lutte-06 macrofloral record. Occurrences of the taxa are in red, in blue are the occurrences on which the age determination was based.

This revision of the palaeobotanical age-interpretation is more in agreement with the previous palynological interpretations (Van de Laar \& Van der Zwan, 1996; see also Fig. 15) that suggested the presence of a Stephanian-Autunian palynoflora in the De Lutte Formation (Assemblage III). Yet there still is a discrepancy. Assemblage III corresponds to the earliest Stephanian (Cantabrian) macrofloral interval recognized in this study (interval $2781.24-2781.45 \mathrm{~m}$ ) rather than to a relatively 
late Stephanian interval (Fig. 15). Due to the lack of Stephanian palynological records in the North Sea area (McLean et al., 2005) any age interpretation based on palynology still remains tentative for the De Lutte Formation. As mentioned by Van de Laar \& Van der Zwan (1996), but also Van der Zwan et al. (1993), the assemblage from the De Lutte Formation is similar to latest Carbonifeous-earliest Permian assemblages from different parts of the world: Donetz Basin (Inosova et al., 1976), Canada (Barss et al., 1963), Germany (Helby, 1966), Western Europe (Clayton et al., 1977), USA (Gupta, 1977), Australia (Balme, 1980), Libya (Brugman et al., 1985, 1988) and Poland (Gorecka \& Gorecka-Novak, 1990). However, in view of the new palaeobotanical evidence and regional geological considerations (presence of the Base Permian unconformity separating the Carboniferous and the Permian Rotliegend Group) a definite Stephanian rather than a StephanianAutunian age may be adopted for Assemblage III. Yet, the 'young' aspect of the assemblage needs further investigation. According to the zonation scheme of Clayton et al. (1977), in the earliest Stephanian interval of the De Lutte Formation one would expect a palynoflora resembling the OT (Thymnospora obscura - Thymnopora thiessenii) Zone. It should be noted, however, that Thymnospora represents tree-ferns characteristic of peat-forming vegetation types, and that the OT Zone is recognized in coal-bearing strata. It is likely that a predominantly coal-free Stephanian facies would give a significantly different palynoflora.

\section{Conclusions}

In contrast to the earlier proposed Westphalian D age, the palaeobotanical re-interpretation of the De Lutte-06 well indicates an essentially Stephanian age for the De Lutte Formation. The study thus confirms the presence of Stephanian strata in the subsurface of the eastern part of the Netherlands. This age determination is in better agreement with earlier palynological data suggesting the presence of a Stephanian-Autunian palynofloras in the De Lutte Formation. However, since these palynofloras co-occur with an earliest Stephanian macroflora, the discrepancy between the palaeobotanical and palynological results is not completely resolved yet. A thorough re-interpretation of the palynology of the De Lutte-06 well is needed.

\section{Acknowledgements}

We thank Dr R. Besems, Shell International Exploration and Production B.V., and Drs D. Chaney, Smithsonian Institution, for their constructive comments. We thank Prof. H. Visscher, Laboratory of Palaeobotany and Palynology, Utrecht University, for his important review comments and Prof. H. Kerp, Department of Palaeobotany, University of Münster, for his both critical and informative review. We thank Drs M. Booi at Naturalis for his help with the pictures.

\section{References}

Balme, B.E., 1980. Palynology, and the Carboniferous-Permian boundary in Australia and other Gondwana continents. Palynology 4: 43-55.

Barss, M.S., Hacequebard, P.A. \& Howie, R.D., 1963. Palynology and stratigraphy of some Upper Pennsylvanian and Permian Rocks of the Maritime Provinces. Geological Survey of Canada Paper 63 (3): 1-13.

Batenburg, L., 1977. The Sphenophyllum species in the Carboniferous flora of Holz (Westphalian D Saar Basin, Germany). Review of Palaeobotany and Palynology 24 (2): 1-10.

Besley B., 2002. Late Carboniferous redbeds of the UK southern North Sea, viewed in a regional context. In: Collinson J., Evans D., Holliday D., Jones N. (eds): Carboniferous hydrocarbon geology. Yorkshire Geological Society, Occasional Publication 7: 225-229

Brongniart, A., 1828. Histoire des végétaux fossils, ou recherches botaniques et géologiques sur les végétaux renfermés dans les diverses couches du globe. Tome premier. Ed. Dufour \& D'0cagne, Paris: 448 pp.

Brugman, W.A., Eggink, J.W., Loboziak, S. \& Visscher H., 1985. Late Carboniferous - Early Permian (Ghzelian-Artinskian) palynomorphs. Journal of Micropalaeontology 4(1): 93-106.

Brugman, W.A., Loboziak, S. \& Visscher H., 1988. The problem of the Carboniferous-Permian boundary from a palynological point of view. In: El-Arnauti, A. Owens, B. \& Thusu, B. (eds): Subsurface palynostratigraphy of North East Libya. Garyouris University publications (Benghazi, Lybia): 151-155.

Clayton G., Coquel, R., Doubinger, J., Gueinn, K. J., Loboziak, S. Owens, B. \& Streel M., 1977. Carboniferous miospores of Western Europe: illustration and zonation. Mededelingen van de Rijksgeologische Dienst 29: 1-71.

Cleal, C.J., 1984. The Westphalian D floral biostratigraphy of Saarland (Fed. Rep. Germany) and a comparison with that of South Wales. Geological Journal 19: 327-351.

Cleal, C.J., 2008a. Palaeoflorsitics of Middle Pennsylvanian lyginopteridaleans in Variscan Euramerica. Palaeogeography, Palaeoclimatology, Palaeoecology 261: 1-14.

Cleal, C.J., 2008b. Palaeoflorsitics of Middle Pennsylvanian medullosaleans in Variscan Euramerica. Palaeogeography, Palaeoclimatology, Palaeoecology 262: in press.

Cleal, C.J., Zodrow, E.L. \& Šimunek, Z., 2007. Leaf cuticles from the Pennsylvanian-aged medullosalean Odontopteris cantabrica Wagner. Acta Paleobotanica 47 (2): 327-337.

Crookall, R., 1969. Fossil plants from the Carboniferous of Rocks of Great Britain. Memoirs of the Geological Survey of Great Britain. Palaeontology 4 (5): XXI-XXVIII and 573-792.

Doubinger, J., Vetter, P., Langiaux, J., Galtier, J. \& Broutin, J., 1995. La flore fossile du bassin houiller de Saint-Étienne. Mem. Mus. Nation. Hist. Nat. 164: 1-355.

Gorecka, T. \& Gorecka-Novak, A., 1990. Palynostratigraphical studies of Upper Carboniferous deposits from the Intra-sudetic Basin, southwestern Poland. Review of Palaeobotany and Palynology 65: 287-292.

Gupta, S., 1977. Miofloral succession and interpretation of the Permian System in the Eastern shelf of North Central Texas, U.S.A. Review of Palaeobotany and Palynology 24: 49-66. 
Hartkopf-Fröder, Ch., 2005. Palynostratigrafie des Pennsylvanium in Deutschland. Courier Forschungsinstitut Senckenberg 254: 133-160.

Heckel, P.H. \& Clayton, G., 2006a. The Carboniferous System. Use of the new official names for the subsystems, series and stages. Geologica Acta 4: 403-407.

Helby, R., 1966. Sporologische Untersuchungen an der Karbon-Perm Grenze in Pfalzer Bergland. Fortschritte der Geologie Rheinland Westfalen 13: 645-704.

Hernandez-Castillo, G.R., Rothwell, G.W. \& Mapes, G., 2001. Thucydiaceae fam. nov., with a review and reevaluation of paleozoic walchian conifers. International Journal of Plant Sciences 162 (5): 1155-1185.

Hilton J. \& Cleal, C.J., 2007. The relationship between Euramerican and Cathaysian tropical floras in the Late Palaeozoic: palaeobiogeographical and palaeogeographical implications. Earth-Science Reviews 85: 85-116.

Inosova K.I., Kruzina, A. Kh. \& Shwartsman, E.G., 1976. Atlas of microspores and pollen from the Upper Carboniferous and Lower Permian of the Donets Basin. Nedra, Moscow. 159 pp. (in Russian).

Jongmans, W.J., 1911. Anleitung zur Bestimmung der Karbonpflanzen WestEuropas. Thallophytae, Equisetales, Sphenophyllales. Mededelingen van de Rijksopsporing van Delfstoffen 3: 482 pp.

Josten, K.-H., 1966. Zur Flora des jügeren karbons (Westfal C bis Stefan) in Nordwestdeutschland und ihr Vergleich mit andere Gebieten. Fortschritte in der Geologie Rheinland Westfalen Band 13 (1). Geologisches Landesamt (Krefeld, Germany): 565-644.

Josten, K.-H., 1970. Bemerkenswerte Pflanzenfossilien aus dem Oberkarbon des Ruhrgebietes (Westfal B) und Piesberges (Westfal D). Abhandlungen Hessisches Landesamt für Bodenforschung 56: 56-64.

Josten, K.-H., 1991. Die Steinkohlen-Floren Nordwestdeutschlands. Fortschritte in der Geologie Rheinland Westfalen Band 36 (1-2). Geologisches Landesamt (Krefeld, Germany): 434 pp.

Josten, K.-H., 1995. Stratigraphie des Oberkarbons: Untersuchung der Makrofloren (Stratigraphy of the Upper Carboniferous: Investigation of the Fossil Plants). DGMK-Bericht 459-3/1: 1-239.

Josten, K.-H., 2005. Florenstratigraphie des Oberkarbons in Nordwestdeutschland. Courier Forschungs-Institut Senckenberg 254: 119-132.

Josten, K.-H. \& Van Amerom, H.W.J., 1999. Die Pflanzenfossielen im Westfal D, Stefan und Rotliegend Norddeutschlands. Fortschritte in der Geologie von Rheinland und Westfalen Band 39. Geologisches Landesamt (Krefeld, Germany): $168 \mathrm{pp}$.

Josten, K.-H. \& Laveine J.P., 1984. Paläeobotanisch-Stratigraphische Untersuchungen im Westfal C-D van Nordfrankreich und Nordwestdeutschland. Fortschritte in der Geologie von Rheinland und Westfalen Band 32. Geologisches Landesamt (Krefeld, Germany): 89-117.

Josten, K.-H. \& Teichmüller R., 1971. Zusammenfassende Übersicht über das höhere Oberkarbon im Ruhrrevier, Münsterland und Ibbenbürener Raum. Fortschritte in der Geologie von Rheinland und Westfalen Band 18. Geologisches Landesamt (Krefeld, Germany): 281-292.

Kerp H., Noll R. \& Uhl D., 2007. Vegetationsbilder aus dem saarpfalzischen Permokarbon. In: T. Schindler \& U.H.J. Heidtke (eds): Kohlensumpfe, Seen und Halbwusten. Pollichia, Sondernveroffentlichung 10: 75-109.

Li Xing-Xue, Shen Guang-Long, Tian Bao-Lin, Wang Shi-Jun \& Ouyang Shu, 1995. Some notes on Carboniferous and Permian floras in China. 244-302. In: Li Xing-Xue (ed.): Fossil floras of China through the geological ages. English edition. Guangdong Science and Technology Press, Guangzhou, China: $695 \mathrm{pp}$.
Lesquereux, L., 1880. Description of the coal flora of the Carboniferous formation in the Pennsylvania and throughout the United States, 1. Board of Commissioners Second Geological Survey (Harrisburg): $694 \mathrm{pp}$.

Lyons, P.C. \& Darrah, W.C., 1989. Earliest conifers of North America: upland and/or paleoclimatic indicators? Palaios 4: 480-486.

Lyons, P.C. \& Zodrow, E.L., 1995. Early to mid-twentieth century floral zonation schemes of the Pennsylvanian (late carboniferous) of North America and correlations with the late Carboniferous of Europe. In: P.C. Lyons, E. Darrah Morey \& R.H. Wagner (eds): Historical perspective of the early twentieth century carboniferous palaeobotany in North America. Geological Society of America Memoir 185: 277-292.

McLean, D., Owens, B. \& Neves, R., 2005. Carboniferous miospore biostratigraphy of the North Sea. In: J.D. Collinson, D.J. Evans, D.W. Holliday \& N.S. Jones (eds): Carboniferous hydrocarbon geology: the southern North Sea and surrounding onshore areas. Occasional Publications Series of the Yorkshire Geological Society 7: 13-14.

Menning, M., Weyer, D., Wendt, I. \& Drozdzewski, G., 2005. Eine numerische Zeitskala des Pennsylvanium in Mitteleuropa. Courier Forschungsinstitut Senckenberg 254: 181-198.

Murphy, A. \& Salvador A., 1999. International Stratigraphic Guide. An abridged version. Episodes 22(4): 255-272.

Raabe, H. \& Remy, W., 1964. Pflanzenfunde in den roten Schichten von Ibbenbüren (vorläufige Mitteilung). N. Jb. Geol. Paläont., Mh, 1964(6): 378-379.

Remy, W. \& Remy R., 1977. Die Floren des Erdaltertums. Verlag Gluckauf GMBH, Essen: $468 \mathrm{pp}$.

Rothwell, G.W., Mapes, G. \& Mapes, R.H., 1997. Late Palaeozoic conifers of North America: structure, diversity and occurrences. Review of Palaeobotany and Palynology 95: 95-113.

Scotese, C.R., 2005. http://scotese.com (website accessed 2008).

Scott, A.C., 1974. The earliest conifer. Nature, 252 (5477): 707-708.

Shi, G.R., 2006. The marine Permian of East and Northeast Asia: an overview of biostratigraphy, palaeobiogeography and palaeogeographical implications. Journal of Asian Earth Sciences 26: 175-206.

Stampfli, G.M. \& Borel, G.D., 2004. A plate tectonic model for the Paleozoic and mesozoic constrained by dynamic plate boundaries and restored synthetic oceanic isochrons. Earth and Planetary Science Letters 196: 17-36.

Van Adrichem Boogaert, H.A. \& Kouwe, W.F.P., 1995. Stratigraphic nomenclature of the Netherlands, revision and update by RGD and NOGEPA. Section C Silesian Group. Mededelingen Rijks Geologische Dienst 50 (1993): 1-40.

Van Amerom, H.W.J., 1996a. The biostratigraphy of borehole 'De Lutte-06' (East Twente, the Netherlands). Mededelingen Rijks Geologische Dienst 55: 83-99.

Van Amerom, H.W.J., 1996b. A new bryophyte species (Hepaticites tortuosus nov. sp.) from the Westphalian D in borehole De Lutte-06, Twente, the Netherlands. Mededelingen Rijks Geologische Dienst 55: 99-106.

Van Buggenum J.M. \& Den Hartog Jager, D.G., 2007. Silesian. In: Th.E. Wong, D.A.J. Batjes \& J. de Jager (eds): Geology of the Netherlands. Royal Netherlands Academy of Arts and Sciences (Amsterdam): 43-62.

Van de Laar, J.G.M. \& Van der Zwan, C.J., 1996. Palynostratigraphy and palynofacies reconstruction of the Carboniferous of borehole 'De Lutte-06' (East Twente, the Netherlands). Mededelingen Rijks Geologische Dienst 55: 61-82. 
Van der Meer, M. \& Pagnier, H.J.M., 1996. Sediment petrography of sandstone bodies of borehole 'De Lutte- 06 ' (East Twente, the Netherlands) and its regional significance. Mededelingen Rijks Geologische Dienst 55: 31-60.

Van der Zwan, C.J., Van de Laar, J.G.M., Pagnier, H.J.M. \& Van Amerom,

H.W.J., 1993. Palynological, ecological and climatological synthesis of the Upper Carboniferous of the well De Lutte-06 (East Netherlands). Comptes rendus XII ICC-P 1: 167-186.

Wagner, R.H. \& Alvarez-Vasquez, C., 1991. Floral characterisation and biozones of the Westphalian D stage in NW Spain. Neues Jahrbuch für Palaeontologie Abhandlungen 183: 171-202.

Wagner, R.H. \& Spinner, E., 1974. The stratigraphical implications of the Westphalian D macro- and microflora and the Forest of Dean Coalfield (Gloucestershire) England. Proceedings 24th International Geological Congress, 1972, Section 7 (Montreal): 428-437.

Wagner, R.H., Villegas, F.J. \& Fonolla, F., 1969. Description of the lower Cantabrian stratotype near Tejerina (Léon-NW Spain). Comptes rendus du 6-ième Congrès International de le Stratigraphie Géologique du Carbonifère (Washington, 1979) 2: 109-134.

Zeiller, R., 1880. Végétaux fossiles du terrain houiller de la France. Extrait du Tome IV de l'explication de la carte géologique de la France: 181 pp. 